University of Nebraska - Lincoln

DigitalCommons@University of Nebraska - Lincoln

Faculty Publications in the Biological Sciences

Papers in the Biological Sciences

6-1898

\title{
The Vegetation Regions of the Prairie Province
}

Roscoe Pound

University of Nebraska - Lincoln

Frederic Clements

Follow this and additional works at: https://digitalcommons.unl.edu/bioscifacpub

Part of the Life Sciences Commons

Pound, Roscoe and Clements, Frederic, "The Vegetation Regions of the Prairie Province" (1898). Faculty Publications in the Biological Sciences. 18.

https://digitalcommons.unl.edu/bioscifacpub/18

This Article is brought to you for free and open access by the Papers in the Biological Sciences at DigitalCommons@University of Nebraska - Lincoln. It has been accepted for inclusion in Faculty Publications in the Biological Sciences by an authorized administrator of DigitalCommons@University of Nebraska - Lincoln. 


\title{
Botanical Gazette
}

\author{
$\mathcal{F U N E} \quad 1898$
}
THE VEGETATION REGIONS OF THE PRAIRIE PROVINCE.

Roscoe Pound and Frederic E. Clements.

(WITH PLATE XXI)

THE vegetative covering of the North American continent falls naturally into two great areas, forest and plain. At first thought it would seem that these were primary phytogeographical divisions, but a comparison with the vegetative covering of other continents proves the contrary. Considered as a phytogeographical feature, the North American forested area is an entity; from a floristic or formational standpoint, it may be analyzed into several distinct portions of widely separated relationship. The ground-tone of the great bulk of the North American forests is that of the forests of British North America, which are closely related to those of middle-north Europe and Siberia, constituting with them the northern realm of Drude and the sub-arctic region of Engler. Three great belts extend southward from this northern mass, each undergoing profound changes in type, and becoming differentiated into well-characterized regions. The floristic separation of these regions from the northern forest-region is so great that the relationship is always much less close than that existing between the floral covering of British America and that of northern Eurasia, and in one or two cases it practically disappears. The forests of Mexico and Central America are tropical, or subtropical, and are both $38 \mathrm{I}$ 
floristically and formationally distinct from the northern forests. So different are certain portions of the plains with respect to vegetative covering that they may be regarded as scarcely more than topographically similar. If North America were to be considered alone, a primary division of the vegetative covering into forest and plain would be useful in certain respects. But these areas are merely the North American representatives of certain zones or realms among those into which the vegetation of the entire earth is divided. In consequence they are not to be distinguished as phytogeographical divisions at all, but as aggregates of divisions, which are characterized by a common type of vegetation-form, or by a group of such types.

Grisebach, having in mind apparently only the gross features of the continental floral covering, distinguished but four divisions, forest domain, prairie domain, Californian littoral domain, and Mexican domain. In the prairie domain he includes not only the prairies proper and the great plains, but the great basin, and the high plateaux of Arizona and New Mexico as well, styling them eastern, northern, and southern prairies respectively. Grisebach practically disregards the true, or eastern prairies, characterizing only the northern and southern ones, which are by no means prairies in a phytogeographical sense, and scarcely more in a physiographical one. As a result of more careful analytical study of the floristic features of the continent, Engler has separated the floral covering into seven provinces: (I) North American lake province, (2) Appalachian province, (3) Prairie province, (4) Californian coast province, (5) Oregon province, (6) Rocky mountain province, (7) Colorado province, the last comprising the vast unforested region between the Rocky mountains and the Sierra Nevada. In 1887, in the Atlas der Pflanzenverbreitung, disregarding division into provinces, Drude outlines a number of vegetation regions upon the floral map of North America, which correspond to the regions proposed in his Handbuch der Pflanzengeographie. These are fourteen in number: ( I ) Glacial forest and thicket region of Alaska, (2) Canadian forest region, (3) forest region of the North 
American lake country, (4) Columbian littoral forest region, (5) forest and alpine region of the northern Rocky mountains, (6) northern forest-prairie region, (7) Missouri prairie region, (8) steppe and salt-waste region of the Rocky mountains, (9) Californian lowland, subalpine and alpine region, (Io) deciduous forest region of the Mississippi basin, ( I I ) evergreen region of the South Atlantic states, (I 2) steppe and desert region of Arizona, (13) chaparral region of Texas and northern Mexico, (14) North Mexican subalpine and alpine region. Many of these regions are well defined, while others manifest too great reliance upon inaccurate data. This is especially evident in the case of the Missouri prairie region, which is erroneous both as to boundary and as to characterization. Drude makes the eastern boundary of this region follow the west bank of the Mississippi to the confluence of the Ohio, where it bends to the east to include the greater portion of Illinois, then turns westward along the southern border of Wisconsin to the Minnesota valley, whence, passing into the northern forest-prairie region, it runs northwest to Beaver river in Saskatchewan, and then southwest to the head waters of the Saskatchewan in the foothills of the Rocky mountains. Taking the western border of the 20 per cent. wooded area as the line of demarcation between the forests of the Alleghany province and the prairie province, the eastern third of Texas, most of the Indian territory, nearly the whole of Missouri, and the southern portion of Iowa, belong to the forested province. Even if a much higher per cent. of woodland be thought necessary to characterize an area as forested, the dense woods of Louisiana, Arkansas and Missouri are indubitable evidence that these states are an integral part of the Alleghany province. To the north of the prairies of the Missouri, Drude distinguishes the prairies and plains of Manitoba, Saskatchewan, Alberta, and Athabasca as the northern forest-prairie region. As will be demonstrated later, these are essentially identical with Missouri prairies, and are in no wise to be distinguished from them. Along the Rocky mountains, Drude refers a broad strip of plain and foothill, comprising a 
large portion of Montana, western Dakota, eastern Wyoming and Colorado and western Nebraska, to a transition-region, connecting the prairies proper with the elevated plains of the Great Basin country. The eastern foothills of New Mexico are included by him in the steppe and desert region of Arizona. Topographically and phytogeographically, the foothills along the eastern border of the Rocky mountains are an intrinsic portion of the great plains, and, as such, are to be included in the prairie province. On the south, while extending the domain of the prairies to the Gulf of Mexico, Drude distinguishes the prairies beyond the Canadian river as southern prairies. It is doubtful whether he would have us consider this a region; at any rate he does not expressly term it such, as is the case with the Saskatchewan prairies. However, a glance at the flora of the geographical extremes of the prairie province will demonstrate that neither the northern nor the southern prairies are regionally distinct from the central mass, but that they merely manifest such "shading-out" as is always present toward the confines of large vegetation-regions.

Turf-builders are the most important vegetation-form for the characterization of the prairies, and in determining the floral contrast between regions, and the degree of such contrast, they are first to be considered. Of the thirty-three species of grasses which comprise the facies and the principal species of the prairie province formations, the prairies of Nebraska, Kansas, and the Dakotas possess the entire number; those of Saskatchewan, Manitoba, etc., possess thirty species; and those of the Red river country, twenty-nine species. From this it is seen that the fundament of the floral covering of the prairie province is essentially homogeneous from the northern extreme to the southern extreme. Of the thirty-six species which constitute the formational facies of the prairies, the central prairies (central in a purely geographical sense) possess the full number; the southern prairies thirty-one species; and the northern thirty-two species. Of one hundred and forty species most important with respect to frequence, abundance, or characteristic, eighty-three are 
common to the entire province, while one hundred and twentynine are found throughout the central and southern portions, and ninety-one throughout the central and northern portions. The vegetation-center of the prairies is found in Nebraska, Iowa, Kansas, and the Dakotas. From this center the typical plains flora slowly shades out toward both north and south; naturally enough over a country so little diversified with about equal rapidity. The effect of higher altitudes and greater distance from the vegetation-center accounts for the greater ultimate reduction in number of species to the northward. The fact that species of distinctly northern range are found only in one extreme of the prairie province, or those of southern origin only in the other, is of trifling importance. All vegetation regions, and none more readily than a plains region, where dissemination is so easily effected, borrow floral elements from adjacent regions, and it is only when this invasion has resulted to a pronounced degree that the original floral covering changes aspect. As has been stated above, the facies and principal species of the province are essentially the same throughout, and the comparatively small number of strictly southern, or northern species are of purely secondary importance in the consideration of the floral covering.

In the characterization of the Missouri prairie region, Drude cites Bouteloua oligostachya and Bulbilis dactyloides as the most common prairie grasses. Both of these grasses, in fact, are equaled in abundance and in importance by several species, such as Andropogon scoparius, Aristida purpurea, Stipa comata, Agropyron pseudorepens, and Koeleria cristata, all of which are of the widest distribution. Bulbilis, on the other hand, is entirely lacking over the vast prairies of the Saskatchewan. It may be remarked in passing that the supposed disappearance of buffalo-grass, Bulbilis dactyloides, connected more or less poetically with the vanishing herds of bison, is a popular myth. The buffalo-grass at the present time undoubtedly covers as large an area geographically as it ever occupied within the memory of man, and is quite as abundant over this area, except for the diminution 
due to artificial factors, such as the "breaking" and the cultivation of the prairies. The mistaken idea concerning the distribution of Bulbilis has arisen from the statements of trappers, scouts, and frontiersmen, who invariably confused, and still confuse, Bulbilis and Bouteloua, thus assigning to the former not only its proper geographical area and abundance, but, in addition, that of Bouteloua oligostachya and B. hirsuta. Another popular fallacy is that the blue stems, Andropogon provincialis and $A$. scoparius, are slowly advancing westward across the plains, an advance often connected with the supposed disappearance of Bulbilis. In fact, both species are as truly endemic in the sand hills and foothills as they are on the eastern prairies. In addition to Bouteloua and Bulbilis, Drude enumerates Agropyron pseudorepens, Oryzopsis cuspidata, Stipa viridula, S. setigera, Andropogon Virginicus and $A$. glomeratus as characteristic species. The last two are not found within the prairie province proper, Stipa setigera is common only south of the Arkansas, and S. viridula is abundant only along the foothills, and on the prairies of the extreme north.

That it is impossible for a phytogeographer to treat accurately the floristic and the distribution of a distant flora which he has not seen, is well exemplified in Drude's Florenkarte von Amerika. Quercus rubra, which on his map has a western distribution running from the southwest corner of Nebraska to the mouth of the L'eau-qui-court in the northeast, occurs in the state only in the southeast corner in the red oak-hickory formation of the Missouri woodlands. On the other hand, the western limit of Quercus macrocarpa does not run north and south through the sand hills, but bends to the westward, passing beyond the Nebraskan border into Wyoming and the Black hills of South Dakota. Juglans cinerea and J.nigra, which, according to Drude, scarcely cross the Mississippi, likewise occur in Nebraska. The former is found in the southeast corner of the state; the latter, as a facies of the bur oak-elm-walnut formation, extends halfway across the state along the L'eau-qui-court and the Republican.

The main features of the regional limitation and character- 
ization, and the formations, briefly discussed in this article, are based upon a treatise entitled The Phytogeography of Nebraska, recently published by the authors of the present paper. The data have been extended, however, to cover the entire prairie province, while in the work referred to only the territory embraced in the political limits of Nebraska is considered.

Considering Nebraska alone, the floral covering of the state falls into four vegetation-regions: I. Wooded bluff and meadowland region; II. Prairie region; III. Sand hill region; IV. Foothill region. Region I consists of a narrow strip along the Missouri. It is an arm of the extreme western edge of the Alleghany forests, which projects northward into the prairie province as far as the Great Bend of the Missouri. Although almost surrounded by prairies, it is in no sense a portion of the prairie province. It is a portion of the Mississippi-basin region. On the central plains, especially those of Nebraska and Kansas, regions II, III, and IV are well-differentiated, both topographically and phytogeographically. As physiographic features, the prairies proper (including those of Iowa and Illinois), extending from the forest to the 98 th meridian, are easily distinguished from the sand hills, and the latter, finding a general western boundary between $102-103^{\circ} \mathrm{W}$., are very distinct from the foothills. To the south, in the Indian territory, the prairies proper are crowded out by the sandy plains, and the prairie region disappears, leaving regions III and IV. On the Saskatchewan plains, the forests close in on the east, and the sandy plains drop out, resulting in a similar reduction, though here it is region III which disappears. Isolated areas of sandy coteau or coulée occur more or less frequently, however, so that most of the sand hill xerophytes are represented. The more typical species, such as are characteristic of sandy fastnesses, like the Loup district in Nebraska, are necessarily lacking. As a consequence of the stronger development of region II to the northward and of region III to the southward, the division of the prairie province gives to it a peculiar dovetailed appearance. The prairie region tapers gradually to the south, finally dis- 
appearing in the Indian territory. The sand hill region likewise narrows toward the north, but much more rapidly, vanishing in the Dakotas, and attaining only occasional expression to the northward. The submontane region IV skirts the base of the Rocky mountains from Athabasca to New Mexico.

It is unnecessary to speak at length of the physiography of the three regions. The most noticeable topographic feature that gives character to the floral covering is soil composition. This, with altitude and precipitation, comprises the great factors which have brought about the differentiation of the prairies into three regions. Thus, while the prairies proper differ in the character of their gently undulating surface from the ridged and broken sand hills, and from the elevated tablelands of the foothills with their precipitous cañons, the important fact for the floral covering is that the soil of the prairie is a close loam instead of a loose sand, as in the sand hills, or an argillaceous marl, as in the foothills. Secondary to this only, is the decrease in precipitation, and the increase in altitude from the eastern boundary of the province to the western. Of equal if not greater importance for the flora is the question of environment, i.e., the derivation of the floral elements. The vegetative covering of the foothills is derived primarily from the mountains, with the exception of the fundament which it has in common with the other regions. That of the prairies proper has come in part from the wooded region to the east. The flora of regions II and IV is a derived one, and the regions may be termed open. The sand hills, while they have drawn somewhat from II and IV, are at no point in direct contact with the flora of another province. The flora is to a large degree endemic, and the region is more or less closed.

The characteristic formations of the prairie province are xerophytic, occasionally poophytic. These are meadow, prairie, sand hill and foothill formations. Not infrequently, certain ruderal formations of xerophytic character acquire great prominence, as in the Niobrara district of the sand hill region. Meadow formations are never xerophytic, but always mesophytic 
or poophytic. Naturally, they occur throughout the three regions. The central portion of the prairie province possesses but a single type of meadow formation, the long-stemmed grass meadow, in which the facies are Elymus Canadensis, Stipa spartea, Agropyron pseudorepens, Panicum virgatum, Andropogon provincialis, and Spartina cynosuroides. This meadow formation exhibits a number of aspects in different stations. It is frequently reduced to a single facies. In sloughs and low meadows, this facies is Spartina cynosuroides; over certain upland meadows, it is Stipa spartea. The most common association of facies is that of Elymus Canadensis, Panicum virgatum, Agropyron pseudorepens, and Andropogon provincialis, which occur in meadows throughout, especially in the sand hills. The prairie and sand hill formations attain their fullest expression in their respective regions, but are not necessarily confined to them. Both prairie formations occur in the dry valleys of the sand hill region, and the bunch grass formation of region III is found upon the sub-sand hills of the prairie region. Foothill formations, on the contrary, are restricted to their proper region.

Prairie formations are of two types, the prairie grass, and the buffalo grass formation. The former covers the eastern portion of the prairie region, Illinois, Iowa, eastern Dakota, Nebraska and Kansas. The facies are species of Sporobolus, Koeleria cristata, Eatonia obtusata, and Panicum Scribnerianum. Frequently the facies of the meadow formations enumerated above assume sufficient abundance on the prairies to warrant ranking them as facies of the prairie grass formation. Like most formations of regions possessing a long growing period, the prairie grass formation manifests two different temporal aspects, a vernal and an estival-serotinal aspect. During the former, the ground-tone of the formation is due to the uniform green of its facies, which is slightly variegated by Draba Caroliniana, Antennaria campestris, Anemone Caroliniana, Baptisia bracteata, Astragalus crassicarpus, etc. The extremes of the estivalserotinal aspect might well be separated, if the one group did not pass so gradually and completely into the other. Two 
groups, the one earlier, the other somewhat later, may be distinguished, however. The former comprises Amorpha canescens, Kuhnistera candida, Psoralea floribunda, Solidago rupestris, S. rigida, Verbena stricta, $V$. hastata, etc.; the latter, Laciniaria squarrosa intermedia, L. scariosa, L. punctata, Vernonia gigantea, Aster sericeus, and the aianthous bloomer, Aster multiflorus.

The buffalo grass formation is characterized by two types, the Bulbilis type and the Bouteloua type. The geographical area of the former is large, but greatly interrupted, and, while the facies manifests great abundance, its frequence is not comparable to that of Bouteloua oligostachya or Andropogon scoparius. The dense mats of buffalo grass render this formation fairly exclusive, except where it is interrupted. The number of secondary species is small. They are for the most part reduced facies of adjacent formations, Aristida purpurea, Agropyron pseudorepens, Distichlis spicata stricta, Koeleria cristata, and the ubiquitous Boutelouas. The ground-tone of the formation is communicated to it by the buffalo grass. Asclepias pumila and Verbena bipinnatifida, though characteristic of this formation, have little effect upon it. Amorpha canescens, Kuhnistera candida, and Solidago Missouriensis are common in this as in the prairie grass formation. The fullest development of this formation is found in the Dakotas, and eastern Montana, from which it extends southward through Nebraska and Kansas. The Bulbilis type prevails, for the most part upon argillaceous table lands. On the other hand, the Bouteloua type is found over sandy stretches, and hence is characteristic of the transition area between the prairies and the sand hills. ${ }^{\mathrm{x}}$

The sand hill formations are three, the bunch grass, the blow out and the sand draw formations. The first covers by far the larger portion of the sand hills, and sandy plains of region III ; the other two are restricted to the topographic features from

The facies is Boutelona oligostachya, replaced on the bottoms of long cañons by $B$. curtipendula. The former is scarcely less exclusive than Bulbilis in typical situations, where it composes from 92 to 98 per cent. of the vegetation. In the transition area between regions II and III it admits a number of secondary species, such as Solidago mollis, Lygodesmia juncea, Plantago Purshii, etc. 
which they are named. The bunch grass formation exhibits two types, the blue-stem formation, which reaches its chief development in the sand hills proper, and the beard grass formation, which is characteristic of sandy plains and sub-sand hills. Both are open formations of a pronounced type ; in the first, the individuals are $\mathrm{I}-3$ meters apart. Owing to the xerophytic nature of these formations, not only are the grasses bunched, but nearly all principal and secondary species assume the tufted habit. An additional characteristic directly traceable to the same conditions is the exceedingly long tap root developed by most sand hill inhabitants. The facies of the blue-stem formation are Andropogon scoparius, Stipa comata, Calamovilfa longifolia, and Andropogon Hallii. The first is the most characteristic on account of the striking bunches which it forms. Stipa comata is especially frequent and abundant. In certain situations, both are to a considerable extent replaced by Calamovilfa longifolia, Andropogon Hallii, and even at times $A$. provincialis, all of which except the last occur throughout the formation. The secondary species are Eragrostis trichodes, Oryzopsis cuspidata, Muhlenbergia pungens, Bouteloua hirsuta, B. oligostachya, Sporobolus cryptandrus, and Cyperus Schweinitzii. Important modifications of this formation are imparted to it by the sand-cherry, Prunus Besseyi, prairie rose, Rosa Arkansana, Amorpha canescens, Ceanothus ovatus and Yucca glauca. The number of secondary species is so great that only the most conspicuous can be mentioned: such are Cycloloma atriplicifolium, Froelichia Floridana, Eriogonum annuum, Chrysopsis villosa, Eriocarpum spinulosum, Opuntia humifusa, Cactus viviparus, Psoralea lanceolata, etc.

The facies of the beardgrass formation are Aristida purpurea, A. basiramea, and Sporobolus cuspidatus, and more rarely Stipa spartea. Where this formation touches the bluestem formation. there is necessarily an intermingling of facies. Secondary species of grasses are very much the same for both formations: Evagrostis pectinacea, Panicum Scribnerianum, Aristida oligantha, Koeleria cristata and Eatonia obtusata are usually more abundant in the beardgrass type. Of other secondary species, in addition 
to those enumerated in the blue-stem formation, are Helianthus petiolaris, Potentilla arguta, Argemone alba, Plantago Purshii, Linum rigidum, etc.

The blowout formation is restricted to peculiar crateriform hollows formed by the action of the wind, and termed "blowouts." In its young and typical condition, it is the most open of all plains formations. It occurs, of course, only in the sand hills proper, since it is here only that blowouts are formed. The facies of the formation are Redfieldia flexuosa, Muhlenbergia pungens, Eragrostis trichodes, Oryzopsis cuspidata, and Calamovilfa longifolia. The colonization of a recently formed blowout is brought about by means of Redfieldia flexuosa, which is uniformly the first grass to make its appearance in these hollows of shifting sand. The slight stability imparted to the sand by it enables Muhlenbergia pungens and Evagrostis trichodes to secure a foothold. These are followed by other grasses, and then by such secondary species as Tradescantia Virginica, Eriogonum annum, Meriolix serrulata, Lathyrus ornatus flavescens, Phaca longifolia, and Euphorbia petaloidea. By this time the sand of the blowout has ceased to shift, and a host of ordinary sand hill inhabitants appear, resulting in the complete reclamation of the blowout and the decadence of the formation which characterized it. The process of reclaiming a blowout is very gradual, and the period between the incipience and the decadence of such a formation is often as much as ten years.

The sand draw formation has much in common with the blowout formation. It is less frequent, however, and is not so well characterized. Oddly, the grasses are not the controlling species. Their place is taken by Cristatella Jamesii, and Polanisia trachysperma. In a typical sand draw, the grasses are represented only by scattered tufts of Munroa squarrosa, Eragrostis major, Sieglingia purpurea, and Paspalum setaceum. The most frequent secondary species are Euphorbia petaloidea, E. hexagona and E. montana.

The foothill formations are three, (I) the undershrub formation of table lands and bad lands, (2) the mat and rosette 
formation of buttes and hills, (3) the grass formation of high prairies and sandy plains. The undershrub formation is not peculiar to the foothills of the prairie province; it here covers but a small area in comparison with the vast stretches occupied by it in the Great Basin province. In the foothills, this formation exhibits two types, the one confined to high, somewhat grassy table lands, the other found solely on alkaline lands, or bad lands. The former may be termed the sagebrush type, the latter the greasewood-white-sage type. The facies of the sagebrush formation are Artemisia tridentata, A. frigida, A. filifolia, $A$. canadensis, and A. cana, Chondrophora Howardii, C. nauseosa, and C. Douglasii, and Gutierrezia Sarothra. The grasses are species of Bouteloua, Agropyron, and Koeleria cristata. The facies of the greasewood-white-sage formation are Sarcobatus vermiculatus, Eurotia lanata and Atriplex confertifolia. Grasses are practically absent. Other secondary species are few. Ptiloria tenuifolia, Aster multiflorus, Cryptanthe Fendleri, and Chrysopsis villosa are the most important.

In the foothills of the central portion of the prairie province, the mat and rosette formations are the most widely distributed. Mats and rosettes have almost exclusive control of buttes, cliffs, rocky ridges, and sandy hillsides. Two types may be distinguished, the mat formation of buttes and cliffs, and the rosette formation of sandy hillsides. No well-marked group of facies is regularly present. The ground-tone of the mat formation is derived from a large number of mat-forming species, Arenaria Hookeri, Gilia spicata, Orophaca caespitosa, Eriogonum cernuum, E. favum, Gilia iberidifolia, Phlox Hoodii, and Homalobus montanus. The secondary species are for the most part invaders from the sand hills, such as Meriolix serrulata, Malvastrum coccineum, Rumex venosus, Psoralea lanceolata, Aristida purpurea, Muhlenbergia pungens, etc. The rosette formation takes its character from Polygala alba, Paronychia Jamesii, Pentstemon albidus, P. caeruleus, Phlox Douglasii, and Oreocarya suffruticosa. This formation is, in reality, transitional between the mat and the grass formations of the foothills, and its secondary species are derived chiefly from them. 
The grass formations are more or less intermediate between the sand hill and the foothill formations, and serve to connect the two regions. The facies are two, Stipa comata and Agropyron pseudorepens each giving character to a more or less distinct type. The Stipa formation predominates over high prairies, the Agropyron formation upon level, sandy plains. The first exhibits a striking group of secondary species, which, from their constant association, and the uniformly blue color of their flowers, lend a distinctive character to the formation. These are Lupinus plattensis, Astragalus mollissimus, A. adsurgens, Spiesia Lamberti and Psoralea argophylla. The Agropyron formation is much more open than the preceding, and is of a more indefinite type.

Halophytic and ruderal formations play a more or less prominent part in the constitution of the floral covering of the prairie province, but they are rarely characteristic, and hence scarcely within the scope of a short paper.

The University of Nebraska.

\section{EXPLANATION OF PLATE XXI.}

Sketch map of the "Prairie Province:" I, the prairie region; II, the sand hill region; III, the foothill region. 


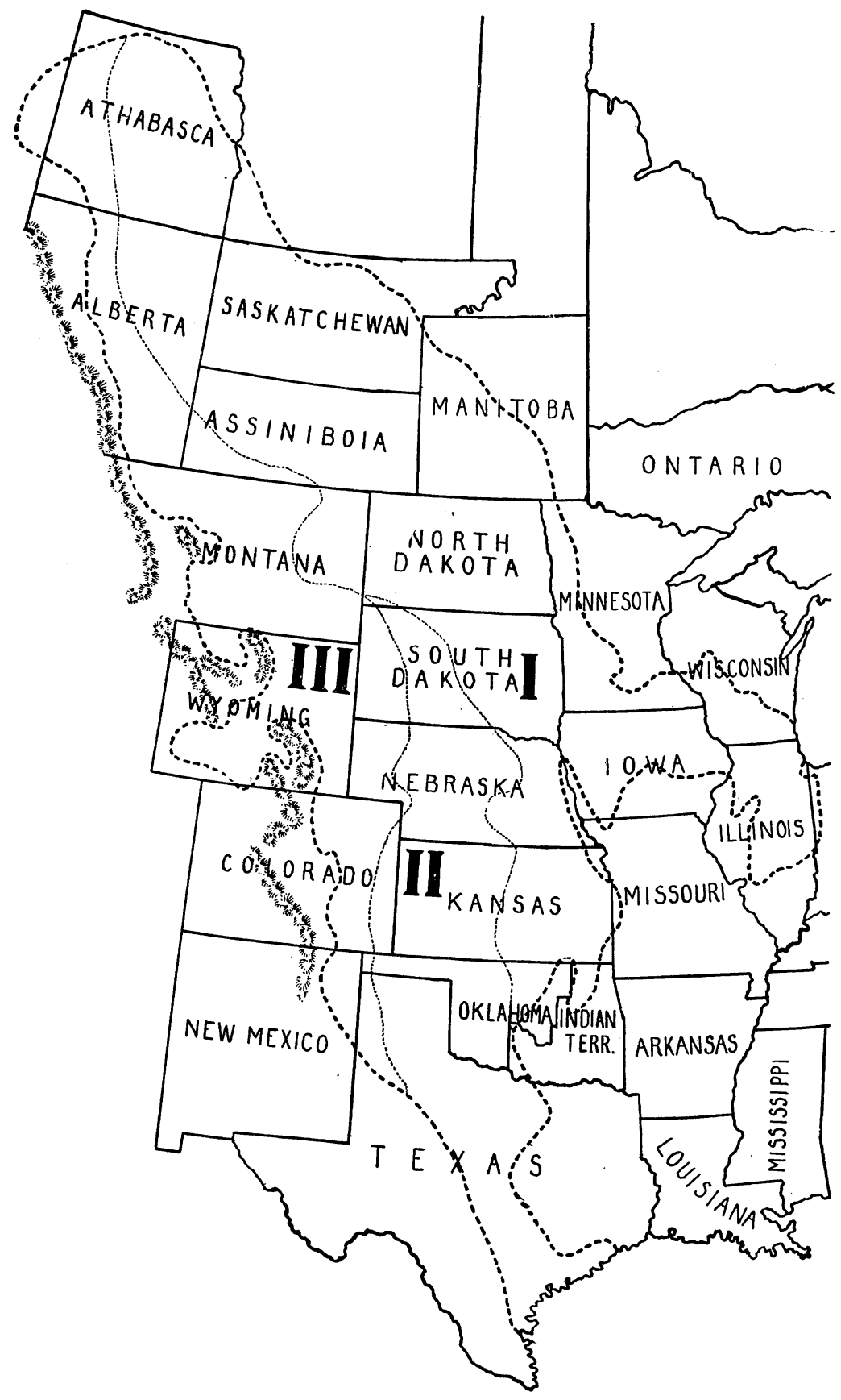

POUND and CLEMENTS on PRAIRJE PROVINCE. 